\title{
Pengaruh Metode SAS (Struktural Analisis Sintesis) Tehadap Peningkatan Keterampilan Membaca Permulaan Pada Siswa Kelas II SDN Mappala Kecamatan Rappocini Kota Makassar
}

\author{
Ahmad Syawaluddin ${ }^{1}$, Muh. Faisal ${ }^{2}$, Risal ${ }^{3}$ \\ ${ }^{123}$ Program Studi PGSD FIP Universitas Negeri Makassar \\ 1ahmad.syawaluddin@unm.ac.id \\ 2muhammad.faisal@unm.ac.id \\ ${ }^{3}$ risal@gmail.com
}

\begin{abstract}
ABSTRAK
Pengaruh Metode SAS (Struktural Analisis Sintesis) Terhadap Peningkatan Keterampilan Membaca Permulaan pada Siswa Kelas II SDN Mappala Kecamatan Rappocini Kota Makassar. Permasalahan dalam penelitian ini yaitu masih rendahnya kemampuan siswa dalam keterampilan membaca permulaan. Adapun rumusan masalahnya adalah apakah terdapat pengaruh metode struktural sintesis analisis (SAS) terhadap peningkatan keterampilan membaca permulaan pada siswa kelas II SDN Mappala Kecamatan Rappocini Kota Makassar?. Tujuan penelitian ini adalah untuk mengetahui pengaruh metode struktural sintesis analisis (SAS) terhadap peningkatan keterampilan membaca permulaan pada siswa kelas II SDN Mappala Kecamatan Rappocini Kota Makassar dalam proses pembelajaran. Pendekatan yang digunakan dalam penelitian ini adalah kuantitatif dengan jenis penelitian adalah eksperimen, dengan tahap Pre Test, treatment, dan Post Test. Desain penelitian yang digunakan adalah pre experimental design yang merupakan bentuk desain penelitian one group Pre Test postest design. Adapun populasi dan sampel penelitian ini adalah siswa kelas II SDN Mappala Kecamatan Rappocini Kota Makassar dengan jumlah siswa 30 siswa. Teknik pengumpulan data yang digunakan adalah tes, dokumentasi dan observasi. Teknik analisis data yang digunakan yaitu analisis statistik deskriptif, uji normalitas, uji hipotesis (uji-t), dan paired sample t-test. Keterampilan membaca permulaan sesudah pemberian perlakuan menggunakan metode SAS lebih meningkat dibandingkan sebelum pemberian metode SAS dalam proses pembelajaran. Setelah dilakukan pengujian hipotesis dengan menggunakan uji-t menunjukkan bahwa terdapat perbedaan yang secara signifikan antara keterampilan memnaca permulaan siswa. Kesimpulannya metode SAS memberikan pengaruh positif terhadap keterampilan membaca permulaan pada siswa kelas II.
\end{abstract}

Kata Kunci: Kemampuan Membaca Permulaan, SAS

\section{PENDAHULUAN}

Pendidikan merupakan

proses

pengubahan sikap dan tata laku seseorang atau kelompok orang dalam usaha mendewasakan manusia melalui upaya pengajaran dan latihan, proses perbuatan, cara mendidik. Pelaksanaan pendidikan juga memiliki tujuan untuk mengembangkan potensi peserta didik meliputi potensi afektif, kognitif dan psikomotor. Pengertian pendidikan tersebut senada dengan rumusan pendidikan dalam Undang-Undang No. 20 Tahun 2003 tentang Sistem Pendidikan Nasional.

Pendidikan adalah usaha sadar dan terencana untuk mewujudkan suasana belajar dan proses pembelajaran agar peserta didik secara aktif mengembangkan potensi dirinya untuk memiliki kekuatan spiritual keagamaan, pengendalian diri, kepribadian, kecerdasan, akhlak mulia, serta keterampilan yang di perlukan dirinya, masyarakat, bangsa dan negara.

Pembelajaran bahasa Indonesia memiliki kedudukan yang sangat penting. Bahasa Indonesia merupakan mata pelajaran yang wajib untuk semua jenjang pendidikan termasuk untuk siswa SD. Menurut Tarigan (1986: 1) ada empat keterampilan berbahasa dalam kurikulum di sekolah, yakni keterampilan mendengarkan, membaca, berbicara dan menulis. Siswa SD diharapkan mampu untuk menguasai keempat komponen kebahasaan tersebut. 
Salah satu keterampilan berbahasa yang sangat penting untuk dimiliki adalah Keterampilan membaca karena merupakan salah satu kunci keberhasilan siswa dalam meraih kemajuan. Siswa yang memiliki keterampilan membaca yang memadai akan lebih mudah menggali informasi dari berbagai sumber tertulis. Maka dari itu keterampilan dan kemauan membaca hendaknya ditekankan sejak jenjang pendidikan dasar yaitu saat anak masih berada di bangku SD. Upaya pengembangan dan peningkatan keterampilan membaca dilakukan melalui pembelajaran di sekolah-sekolah dasar sebagai pengalaman pertama. Terkait dengan pernyataan tersebut, Darmiyati Zuchdi dan Budiasih (1997: 50) berpendapat bahwa keterampilan membaca permulaan akan sangat berpengaruh terhadap kemampuan membaca lanjut. Sebagai keterampilan yang mendasar maka keterampilan membaca permulaan benar-benar memerlukan perhatian guru.

Keterampilan membaca menjadi salah satu masalah yang harus diperhatikan oleh guru khususnya guru di kelas II SD negeri Mappala Kecamatan Rappocini Kota Makassar. Fakta yang ditemukan peneliti saat melakukan observasi pada bulan September 2017 menunjukkan bahwa masih ada beberapa siswa yang belum lancar membacanya atau masih belum fasih dalam membaca suatu bacaan.

Fakta ini diperkuat dengan persentase hasil ujian semester siswa kelas II SDN Mappala Kecamatan Rappocini Kota Makassar yang memenuhi nilai KKM (nilai kriteria ketuntasan minimal pada bahasa indonesisa dalam keterampilan membacanya adalah 65 dari 30 siswa. Dengan demikian, hasil belajar siswa kelas II SDN Mappala Kecamatan Rappocini Kota Makassar belum mencapai target yang diharapkan yaitu $75 \%$ siswa memperoleh nilai $\geq 70$. Siswa sudah mengenal semua huruf tetapi masih belum bisa merangkai huruf menjadi suku kata dan kata. Tetapi masih ada siswa yang belum bisa melafalkan abjad dengan tepat, sehingga pada waktu membaca lafal yang diucapkan belum benar. Contohnya siswa membaca kata /i-kan/ dibaca /iiiiikkkkkaaan/, kata kuda dibaca /kkkkuuuddda/. Permasalahan tersebut disebabkan metode yang diterapkan dalam pembelajaran masih kurang efektif dalam meningkatkan keterampilan siswa dalam membaca. Dalam pembelajaran membaca guru lebih sering menggunakan metode abjad.

Berdasarkan latar belakang di atas perlu dilakukan penelitian tindakan dalam rangka meningkatkan proses pembelajaran membaca permulaan melalui metode kata lembaga dan meningkatkan keterampilan membaca permulaan siswa. Untuk itu, penelitian ini layak dilakukan di SDN Mappala Kecamatan Rappocini Kota Makassar. Berdasarkan uraian di atas maka dapat dikemukakan rumusan permasalahan penelitian ini sebagai berikut: Apakah terdapat pengaruh metode struktural sintesis analisis (SAS) terhadap peningkatan keterampilan membaca permulaan pada siswa kelas II SDN Mappala Kecamatan Rappocini Kota Makassar?.

\section{METODE}

Pendekatan penelitian yang digunakan yaitu pedekatan kuantitatif karena peneliti akan mengetahui pengaruh metode struktural analisis sintesis (SAS). Jenis penelitian yang digunakan adalah eksperimen. Jenis ini dipilih karena peneliti akan memberikan treatment terhadap kelas eksperimen yang terlebih dahulu diberikan pretest dan hasil pretest dan posttest sebagai pembandingnya.

Adapun variabel yang menjadi acuan dala penelitian ini yaitu :

a. Variabel bebas (X) : penelitian ini variabel bebasnya yaitu metode SAS

b. Variabel terikat (Y): penelitian ini variabel terikatnya yaitu keterampilan membaca permulaan pada siswa kelas II SDN Mappala Kecamatan Rappocini Kota Makassar.

Berdasarkan eksperimen penelitian yang akan dilaksanakan maka menurut Sugiyono (2015) bahwa penelitian eksperimen ini menggunakan Pre Experimental Design bentuk One Group Pretest Postest Design, di mana desain tersebut yakni:

Keterangan:

$$
\begin{array}{lll}
\boldsymbol{O}_{1} & \mathbf{X} & \boldsymbol{O}_{2}
\end{array}
$$

$\boldsymbol{O}_{1}=$ hasil pretest sebelum diberi perlakuan

$\boldsymbol{O}_{2}=$ hasil posttest setelah diberi perlakuan

$\mathbf{X}=$ perlakuan

Teknik yang digunakan untuk memperoleh data dalam penelitian ini adalah sebagai berikut:

1) Tes

Menurut Collegiate dalam Bundu (2012:

7) mengemukakan definisi "tes yaitu serangkaian pertanyaan atau latihan atau alat 
lain yang digunakan untuk mengukur keterampilan, pengetahuan, intelegensi, kemampuan atau bakat yang dimiliki individu atau kelompok". Tes untuk memperoleh data tentang keterampilan siswa dalam membaca permulaan

\section{2) Dokumentasi}

Data penunjang dalam penelitian ini berupa dokumnetasi yang meliputi daftar nama siswa kelas II baik laki-laki maupun perempuan, kriteria ketuntasan minimal mata pelajaran bahasa Indonesia, dan gambar saat proses pembelajaran sedang berlangsung di kelas II SDN Mappala Kecamatan Rappocini Kota Makassar.

\section{3) Observasi}

Lembar observasi dibuat Observasi dalam penelitian ini dilaksanakan dengan mengamati aktivitas siswa dan guru dalam proses pembelajaran.

Analisis data yang digunakan adalah statistik deskriptif, yaitu statistik yang digunakan untuk menganalisis data dengan mendeskripsikan atau menggambarkan data yang telah terkumpul apa adanya tanpa membuat kesimpulan yang berlaku secara umum (Sugiyono, 2012:147). Berdasarkan pendapat tersebut maka analisis statistik deskriptif dalam penelitian ini digunakan untuk mendeskripsikan keterampilan membaca permulaan siswa ketika diberi perlakuan penggunaan metode SAS.

Pengujian hipotesis penelitian mengenai perbedaan keterampilan membaca permulaan pada siswa SDN Mappala Kecamatan Rappocini Kota Makassar sebelum dan sesudah menggunakan metode SAS, maka dapat dilakukan uji-t dengan menggunakan bantuan program Statistical Package for Social Science (SPSS) versi 20.

Selain itu menggunakan Paired Sample T-Test yang digunakan untuk melihat perbedaan hasil tes sebelum dan setelah diterapkan penggunaan metode SAS pada kelas eksperimen maka data dianalisis dengan menggunakan Paired Samplet t-test. Untuk mencari besar thitung sebelum dan sesudah perlakuan maka digunakan maka dapat menggunakan bantuan program aplikasi Statistical Package for Social Science (SPSS) versi 20.

\section{HASIL DAN PEMBAHASAN}

\section{a. Hasil Penelitian}

1. Hasil Statistika Deskriptif

Penelitian ini dilaksanakan dengan terlebih dahulu meminta persetujuan Kepala Sekolah SD Negeri Mappala Kecamatan Rappocini Kota Makassar mengenai penelitian yang akan dilaksanakan. Setelah itu, peneliti melakukan observasi ke kelas yang akan diteliti. Setelah menentukan kelas tempat pelaksanaan penelitian, peneliti melakukan diskusi dengan guru kelas II untuk menyepakati jadwal penelitian yang akan dilakukan. Penelitian pertama kali dilakukan pada tanggal 13 September 2016 untuk pemberian materi dan tes awal (pretest) pada kelas II. Sebelum peneliti terjun ke lapangan memberikan tes awal (pretest), peneliti terlebih dahulu melakukan uji validitas isi. Validitas isi merupakan validitas yang menyatakan keterwakilan aspek yang diukur dalam instrumen. Validitas isi dibuat dengan bantuan menggunakan kisi-kisi instrumen. Kisi-kisi tersebut terdapat standar kompetensi, kompetensi dasar dan indikator sebagai tolak ukur dan nomor butir pertanyaan atau pernyataan yang telah dijabarkan dari indikator. Berdasarkan butir-butir instrumen yang akan di validasi tersebut kemudian dikonsultasikan pada ahli yang sesuai dengan disiplin ilmu instrumen yang telah dibuat.

Validator yang penulis jadikan sebagai ahli dalam mengkonsultasikan instrumen yang telah dibuat dan sesuai dengan bidang ilmu Bahasa Indonesia sebagai mata pelajaran dalam penelitian ini yaitu Aswati Asri, S.Pd., M.Pd. Instrumen yang diajukan oleh peneliti yaitu RPP, lembar observasi, teks cerita pre test dan post test.

Teks cerita yang telah ditetapkan oleh validator tersebut disesuaikan atas indikator yang menjadi patokan awal dan lebih mengkhusus pada instrumen tentang cerita anak-anak. Hasil instrumen yang telah di validasi tersebut merupakan bobot yang sama dalam melaksanakan pre test dan post test.

a) Tes Awal (Pre test) Kelas II Sebelum Diberikan Perlakuan Berupa Metode SAS

Hasil statistik yang berkaitan dengan nilai tes awal (pre test) siswa pada kelas II, yakni kelas yang akan diberikan perlakuan berupa metode SAS, dapat disajikan sebagai berikut:

Berdasarkan data nilai tes awal (pre test) terlihat bahwa rata-rata nilai yang diperoleh dengan jumlah 30 orang siswa yaitu 71,48 
dengan nilai median 68,80 . Sedangkan standar deviasi yang diperoleh yaitu 5,098 dengan skor minimum 63 dan skor maksimum 88. Selain itu, diperoleh juga besar nilai variance pada data ini yaitu 25,994.

Jika nilai pre test tersebut dikelompokkan kedalam lima kategori maka menunjukkan bahwa keterampilan membaca permulaan siswa sebelum diterapkan metode SAS sebagian besar berada pada kategori baik dimana dari seluruh siswa yaitu sebanyak 30 orang, ada 26 siswa atau $87 \%$. Sedangkan pada kategori sangat baik hanya 1 orang atau 3\% dan pada kategori cukup terdapat 3 siswa atau $10 \%$ serta tidak ada atau $0 \%$ siswa yang memperoleh nilai keterampilan membaca permulaan pada kategori kurang dan sangat kurang.

\section{b) Tes Hasil Belajar (Post test) Kelas II Setelah Diberikan Perlakuan Berupa Metode SAS}

Hasil statistik yang berkaitan dengan nilai tes akhir (post test) siswa pada kelas II, yakni kelas yang akan diberikan perlakuan berupa metode SAS, maka data nilai tes akhir (post test) terlihat bahwa rata-rata nilai yang diperoleh dengan jumlah 20 orang siswa yaitu 82,93 dengan nilai median 81,25 . Sedangkan standar deviasi yang diperoleh yaitu 9,960 dengan skor minimum 69 dan skor maksimum 100. Selain itu, diperoleh juga besar nilai variance pada data ini yaitu 99,204.

Jika nilai post test tersebut dikelompokkan kedalam lima kategori maka menunjukkan bahwa keterampilan membaca permulaan siswa setelah diterapkan metode SAS sebagian besar berada pada kategori sangat baik dimana dari seluruh siswa yaitu sebanyak 30 orang, ada 20 siswa atau $67 \%$. Sedangkan pada kategori baik hanya 10 orang atau $33 \%$ dan tidak ada siswa atau $0 \%$ yang memperoleh nilai keterampilan membaca permulaan pada kategori cukup, kurang dan sangat kurang.

Berdasarkan perhitungan rata-rata, maka dapat disimpulkan bahwa ada pengaruh metode SAS terhadap peningkatan keterampilan membaca permulaan kelas II pada mata pelajaran Bahasa Indonesia. Hal ini dapat dilihat dari perbedaan rata-rata peningkatan keterampilan membaca permulaan yang diperoleh pada kelas II sebelum dan sesudah diberi perlakuan dengan memberi $S A S$. Rata-rata peningkatan keterampilan membaca permulaan (posttest) pada kelas II, yakni ketika diberi perlakuan berupa metode SAS adalah
82,93 sedangkan sebelum diberi perlakuan berupa metode $S A S$ rata-rata peningkatan keterampilan membaca permulaan (pretest) pada kelas II adalah 71,48 tetapi perlu dilakukan uji-t untuk mengetahui apakah berpengaruh secara signifikan atau tidak.

\section{Uji Normalitas}

Analisis data dengan menggunakan uji asumsi yaitu dengan melakukan uji normalitas data. Berdasarkan hasil analisis data dengan menggunakan SPSS Versi 20 diperoleh data uji normalitas pada kelas VB, yakni sebagai berikut:

\begin{tabular}{lc}
\hline & $\begin{array}{l}\text { Kelas II } \\
\alpha(0.05)\end{array}$ \\
\hline Pretest & \multicolumn{1}{c}{ Posttest } \\
\hline $0,076>0.05$ & $0,566>0.05$ \\
P-Value $>\alpha$ & P-Value $>\alpha$ \\
\hline
\end{tabular}

Berdasarkan hasil analisi data dengan menggunakan SPSS Versi 20 tersebut, dapat disimpulkan bahwa sampel berdistribusi normal karena nilai yang diperoleh lebih besar dari taraf signifikan 0,05. Jadi pengujian normalitas terpenuhi sehingga analisis ini menggunakan statistik parametrik.

\section{Pengujian Hipotesis (Uji-T)}

Pengujian hipotesis dalam penelitian ini dilakukan dengan menggunakan uji-t dengan memperhatikan hipotesis penelitian yang telah dirumuskan sebelumnya, diperoleh nilai sebesar 0,000 . Nilai yang diperoleh tersebut lebih kecil dari taraf signifikansi 0,05 yang berarti bahwa terdapat perbedaan secara signifikan pada probabilitas 0,05 hasil belajar kelas II. Hal ini menunjukkan bahwa penerapan metode $S A S$ memiliki pengaruh terhadap peningkatan keterampilan membaca permulaan.

\section{Paired Sample T-test}

Uji paired sample t-test dilakukan dengan menggunakan SPSS versi 20. Uji paired sample t-test dikatakan signifikan apabila nilai sig $<0,05$ kemudian nilai $t$ dan sig. (2-tailed) $<0,05$. Selanjutnya dikatakan tidak signifikan apabila nilai sig $>0,05$ kemudian nilai t dan sig. (2-tailed) $>0,05$.

Hasil yang diperoleh dari kelas II yaitu pada bagian signifikansi lebih kecil dari 0,05 yaitu $0,000<0,05$ maka langkah selanjutnya yang dilakukan oleh peneliti memperhatikan nilai $\mathrm{t}$ dan sig. (2-tailed) yaitu $0,000<0,05$ artinya ada perbedaan signifikan saat pretest 
(sebelum adanya treatment) dan hasil posttest (setelah adanya treatment). Selain itu, berdasarkan data yang telah diperoleh nilai $\mathrm{t}_{\text {hitung }}$ yang diperoleh yaitu $-5,899$ (Lampiran 14). Membandingkan nilai $t_{\text {hitung }}$ dengan $t_{\text {tabel }}$ pada taraf signifikansi $5 \%$ untuk df $(\mathrm{N}-1)=$ $(30-1)=29$. Nilai $t_{\text {tabel }}$ untuk taraf signifikansi $5 \%$ adalah 2,048. Besarnya nilai thitung terletak di daerah penerimaan Ha dengan harga $t_{\text {hitung }}$ adalah harga mutlak, jadi tidak dilihat $(+)$ atau negatif (-)nya. Sehingga Ho ditolak, di mana $t_{\text {hitung }}>t_{\text {tabel }}$ atau $t_{\text {hitung }}(5,899)>t_{\text {tabel }}(2,048)$ maka Ha diterima.

\section{Gambaran Metode SAS}

Metode SAS dapat memberikan kontribusi positif bagi siswa khususnya pada siswa kelas II di SDN Mappala Kecamatan Rappocini Kota Makassar. Hal ini dibuktikan dari hasil observasi yang dilakukan pada siswa sendiri sewaktu melakukan penelitian di sekolah tersebut. Hasil observasi menunjukkan siswa menjadi semangat dalam belajar. Selanjutnya dengan menggunakan metode SAS dalam proses pembelajaran siswa menjadi bersemangat, termotivasi, berkonsentrasi penuh dalam mengikuti pembelajaran, keberagaman diantara siswa dapat dihilangkan. Selain itu, dengan menggunakan metode SAS dapat memberikan suasana yang baru dan menyenangkan dalam setiap proses belajar. Hal tersebut dapat disimpulkan bahwa metode SAS perlu dilakukan atau diberikan kepada siswa karena dapat memberikan manfaat yang positif terhadap situasi pembelajaran.

\section{b. Pembahasan}

Permasalahan yang telah dipaparkan sebelumnya yang menyatakan bahwa apakah terdapat pengaruh yang signifikan metode SAS terhadap peningkatan keterampilan membaca permulaan pada siswa kelas II SD Negeri Mappala Kecamatan Rappocini Kota Makassar dalam proses pembelajaran.

Berdasarkan teori yang dipaparkan bahwa saat dalam suasana yang menyenangkan otak akan mekar dan berkembang seperti spons yang membuat siswa mampu menyerap pelajaran dengan mudah dan cepat. Sehingga apabila siswa senang dalam mengikuti pembelajaran maka pembelajaran di kelas akan semakin aktif dan kemampuan otak dalam menangkap materi pembelajaran juga akan semakin berkembang. Oleh karena alternatif cara yang dapat digunakan dalam kegiatan pembelajaran ini melalui metode SAS yang di mana metode SAS memberikan manfaat yang besar dalam proses pembelajaran. Adapun karakteristik yang dimiliki oleh SAS dapat memberikan kontribusi yang positif dalam proses pembelajaran karena dapat mengarahkan siswa untuk berkonsentrasi dalam kegiatan pembelajaran.

Kegiatan pembelajaran yang menggunakan metode SAS ini memiliki langkah operasional dengan urutan: struktural menampilkan keseluruhan, analisis melakukan proses penguraian dan sintesis melakukan penggabungan kembali kepada bentuk struktural semula.

Kelas II merupakan kelas yang akan dijadikan sebagai objek dalam penelitian yang diajar dengan menggunakan metode SAS. Pertemuan pertama siswa diberikan materi dan tes awal (pretest) dengan alokasi waktu $3 \times 35$ menit. Pertemuan kedua, guru telah menerapkan metode SAS dalam proses pembelajaran peneliti merekam bahasa siswa melalui pertanyaan-pertanyaan disampaikan guru sebagai kontak permulaan kemudian menampilkan gambar sambil bercerita, selanjutnya siswa diajak membaca kalimat secara struktural dengan cara menghilangkan gambar sehingga tinggallah kartu-kartu kalimat yang dibaca oleh siswa. Pertemuan kedua ini, peneliti melakukan analisis terhadap struktur dengan cara memisah-misahkannya menjadi kata, kata menjadi suku kata, dan suku kata menjadi huruf, kemudian melakukan proses sintesis dengan cara menggabungkan kembali setiap unsur tersebut menjadi struktur lengkap seperti semula.

Pertemuan ketiga, peneliti mengajak siswa membaca bahan dengan nyaring secara bersama-sama, kemudian membaca setiap baris kalimat secara bergantian selanjutnya apabila anak belum lancar membaca, dapat diulang kembali atau kembali menggunakan media tanpa buku. Peneliti memperlihatkan pelafalan huruf (vokal dan konsonan) dan tanda baca pada bacaan tersebut dan proses ini dapat dilakukan secara berulang-ulang sehingga anak menjadi terampil membaca.

Pertemuan keempat, peneliti memberikan tes (posttest) kepada siswa dengan membagikan teks cerita yang berjudul "Anak penggembala dan serigala" dan memberikan instruksi untuk membaca teks cerita tersebut satu per satu dengan alokasi waktu 60 menit untuk melihat sejauh mana kemampuan membaca permulaan siswa setelah diberikan perlakuan berupa metode $S A S$.

Berdasarkan hasil perhitungan analisis deskriptif yang telah dilakukan ternyata 
terdapat perbedaan antara peningkatan keterampilan membaca permulaan pada saat tes awal (pretest) dan tes akhir (posttest) setelah diberikannya treatment pada siswa kelas II. Perbedaan ini dapat dilihat pada ratarata nilai tes awal siswa yang diperoleh yaitu 71.48 sedangkan rata-rata nilai tes akhir peningkatan keterampilan membaca permulaan yang diperoleh yaitu 82.93 .

Berdasarkan hal tersebut, maka dapat disimpulkan bahwa proses pembelajaran pada kelas II tergolong baik. Peneliti tidak mengalami kesulitan dalam proses pembelajaran. Sehingga dapat dikatakan bahwa metode $S A S$ yang digunakan dalam proses pembelajaran dapat memberikan dampak positif terhadap proses pembelajaran di dalam kelas.

\section{KESIMPULAN DAN SARAN}

Berdasarkan hasil penelitian terlihat adanya pengaruh metode SAS terhadap peningkatan keterampilan membaca permulaan pada siswa kelas II SDN Mappala kecamatan Rappocini kota Makassar, hal ini dapat diketahui dari hasil analisis data dan pembahasan. Dengan demikian dapat disimpulkan bahwa terdapat pengaruh positif yang signifikan pada metode SAS (struktural analisis sintesis) terhadap peningkatan keterampilan membaca permulaan pada siswa kelas II SDN Mappala kecamatan Rappocini kota Makassar.

\section{DAFTAR PUSTAKA}

Bahasa Indonesia yang Efektif di Sekolah Dasar. Jakarta: Departemen Pendidikan Nasional.

Abdurrahman, Mulyono. 2003. Pendidikan bagi Anak Berkebutuhan Belajar. Jakarta: Rineka Cipta

Ardiyanti, Lia. 2015. Peningkatan Keterampilan Membaca Permulaan Melalui Metode Kata Lembaga Siswa Kelas I SD Karanggayam Kecamatan Pleret Kabupaten Bantul. Skripsi. Yogyakarta

Broto, A.S. 1985. Membaca. Jakarta: Bina Bahasa.

Bundu, Patta. 2012. Asesmen Pembelajaran. Padang: Hayfa Press.

Ernalis. 2006. Penggunaan Metode SAS dalam Pembelajaran Membaca dan Menulis Permulaan di Sekolah Dasar. Mimbar Pendidikan. Volume 4, No. 25.
Hadirah. 2015. Peningkatan Kemampuan Siswa dalam Membaca Permulaan dengan Menerapkan Metode Struktural Analitik Sintetik (SAS) di Kelas I SDN 33 Bilango Kecamatan tondong Tallasa Kabupaten Pangkep. Skripsi. Makassar.

Hairuddin, dkk. 2007. Pembelajaran Bahasa Indonesia. Jakarta: Depdiknas.

Kamus Besar Bahasa Indonesia. 2007. Edisi Ketiga. Jakarta: Balai Pustaka.

Kurikulum Tingkat Satuan pendidikan (KTSP) 2006 Mata pelajaran Matematika untuk Tingkat SD/M/ Jakarta Departemen Pendidikan Nasional.

Rahim, Faridah. 2007. Pengajaran Membaca di Sekolah Dasar. Jakarta: PT. Bumi Aksara.

Rusdiyanto. 2011. Penggunaan Metode SAS dapat Meningkatkan Keterampilan Membaca Permulaan pada Siswa Kelas I SDN 02 Kunduran Kecamatan Kunduran Kabupaten Blora. Skripsi. Semarang.

Safari. 2003. Evaluasi Pembelajaran. Jakarta: Departemen Pendidikan Jenderal Pendidikan Dasar dan Menengah Direktorat Tenaga Kependidikan.

Santoso, Puji. 2007. Materi dan Pembelajaran Bahasa Indonesia SD. Jakarta: Universitas Terbuka.

Santrock, John W. 2014. Psikologi Pendidikan Educational Psychology. Jakarta: Salemba.

Sugiyono dan Kasmadi. 2013. Metode Penelitian Pendidikan Pendekatan Kuantitatif, Kualitatif, dan $R \& D$. Bandung: Alfabeta.

Suhana dan Sunarti. 2000. Strategi Belajar Mengajar Bahasa Indonesia. Bandung: Pustaka Setia.

Suharsini, Arikunto. 2005. Penelitian Tindakan Kelas. Jakarta: Bumi Aksara.

Supriyadi, dkk. 2001. Materi Pokok Bahasa Indonesia 2. Jakarta: Departemen P dan $\mathrm{K}$.

Suprijono, A. 2013. Pembelajaran Kooperatif: Teori \&Aplikasi PAIKEM. Yogyakarta: Pustaka Pelajar.

Tarigan, Henry Guntur. 2013. Membaca sebagai suatu Keterampilan Berbahasa. Bandung: Angkasa

Tim Penyusun. 2012. Pedoman Penulisan Skripsi Program S-1 Fakultas Ilmu Pendidikan UNM. Makassar: FIP UNM. 
Tiro, M. A. 2006. Dasar-Dasar Statistika. Makassar: State University of Makassar Press.

Undang- undang Republik Indonesia Nomor 20 Tahun 2003 Tentang Sistem Pendidikan Nasional.

Yusuf, Muri. 2014. Metode Penelitian Kuantitatif, Kualitatif, \& Penelitian Gabungan. Jakarta: PT. Fajar Interpratama Mandiri.

Zuchdi, Darmiyati dan Budiasih. 1997. Pendidikan Bahasa dan Sastra Indonesia di Kelas Rendah. Jakarta: Dirjen Dikti Depdikbud. 